\title{
The relationship between dental care perception towardoral Health ofpatients with primary hypertension in Padongko Health Center, Barru Regency
}

\author{
Masriadi $^{1}$, Sarafin Aslan ${ }^{2}$, Kurniaty Pamewa ${ }^{3}$, Chusnul Chotimah ${ }^{4}$, Sri Devi ${ }^{5}$ \\ ${ }^{1}$ Professor, Department of Epidemiology, Faculty of Public Health, Universitas Muslim Indonesia, ${ }^{2}$ Instructor, \\ Departement of Conservative Dentistry, Faculty of Dentistry, Universitas Muslim Indonesia, ${ }^{3}$ Instructor, \\ Department of Pedodontic, Faculty of Dentistry, Universitas Muslim Indonesia, ${ }^{4}$ Instructor, Department of \\ Prostodontic, Faculty of Dentistry, Universitas Muslim Indonesia, ${ }^{5}$ Researcher, Departement of Faculty of \\ Dentistry, Universitas Muslim Indonesia
}

\begin{abstract}
Background: The problem of unsanitary dental and that is influenced by several individual perception factors including perception of knowledge, perception of relatives people, and perception of desires. To find out whether the perception of knowledge, perception of relatives people of desires have a relationship toward oral hygiene in respondents with primary hypertension.
\end{abstract}

Material and Method: This research was an analytical observation using cross-sectional study. The population was the patients with primary hypertension, a purposive sampling technique was applied through path analysis test.

Results: The results of the research showed the relationship of perception of knowledge toward primary hypertension, it was obtained p $0.560>\alpha 0.05$, the perception of relatives toward primary hypertension, it was obtained p $0.394>\alpha 0,05$, and the perception of desire toward primary hypertension, it was obtained $p$ value $0.762>\alpha 0.05$. Based on the three variables of perception, Ha obtained has a relationship but does not seem significant. Perception of knowledge toward oral health, it was obtained p $0.368>\alpha 0.05$ so that Ha obtained has a relationship but does not seem significant. Next, perceptions of relatives toward oral health, it was obtained $\mathrm{p}$ value $0.040<\alpha 0.05$. Last, perception of desires toward oral health, it was obtained $\mathrm{p} 0.001$ $<\alpha 0.05$, thus Ha obtained has a significant relationship. The relationship of primary hypertension toward oral health has a significant relationship where the results of $\mathrm{p} 0.012<\alpha 0.05$.

Conclusion: There is a relationship between perception of dental care toward oral health in patients with primary hypertension but it did not appear significantly.

Keywords: Knowledge, Relative, Desires, Primary Hypertension, Oral Hygiene (OHI-S).

\section{Introduction}

Hypertension or famously known as the silent killer is a conditionwherethe increase of blood pressure

\section{Corresponding Author:}

\section{Masriadi}

Professor, Department of Epidemiology, Faculty of Public Health, Universitas Muslim Indonesia

Adress: Jl. Abd. Dg. Sirua No. 155B Makassar, Indonesia

e-mail: arimasriadi@gmail.com above normal. Increased age is one factor causing the occurrence of hypertension, this is due to the increasing age of organ function decreased marked by decreased elasticity of the arteries and stiffness occurs blood vessels so vulnerable to an increase in blood pressure. Hypertension isdefinedas persistent blood pressure where the systolic pressure is above $140 \mathrm{mmHg}$ and diastolic over $90 \mathrm{mmHg}$. 1,2,3,4,5,6 Primaryhypertension is a hypertension which causes is unknown (idiopathic), although it is associated with a combination of certain lifestyle factors such as lack of movement (inactivity) and diet. The prevalence of hypertension is predicted 
to continue increasing, by 2025 it is predicted as many as $29 \%$ of adults sufferingfrom hypertension worldwide. .,8,9,10 $^{2}$

WHO explained that found that around the world there are about 972 million people or $26.4 \%$ people worldwide suffer from hypertension, this number is likely to increase to $29.2 \%$ people in 2025 . Oral hygiene that is not maintained properly will cause disease in the oral cavity. The indicator of oral health is the level of oral and dental hygiene, where the way to maintain oral and dental hygiene is certainly influenced by the treatment in the oral cavity, that is by gargling and brushing the teeth regularly. ${ }^{7,11,12}$

The condition of the oral cavity that is often encountered in patients with primary hypertension is influenced by the numbers of the drugs used that have side effects on the oral cavity condition which is caused by a decrease in the flow rate of saliva which can cause xerostomia. The reduced amount of saliva will also cause the $\mathrm{pH}$ of saliva in the mouth to be low so that the growth of the bacteria Streptococcus Mutans, Lactobacillus, and Candida Albicans increase. ${ }^{13,14,15}$

In patients with primary hypertension whose use of the drug is not regularly as directed by the doctor will be a predisposing factor of someone's oral hygiene and it is supported by cleaning teeth and mouth that is not maintained properly (OHI-S) so that it can cause the conditions there are many debris and calculus in the mouth. 16,17

In general, hypertension does not provide specific symptoms. Generally, the symptoms complained are related to: increased blood pressure (BP), vascular disorders, underlying diseases. For clinical blood pressure classifications include: optimal, nominal, high hypertension, first degree hypertension, second degree hypertension, third degree hypertension, and isolated systolic hypertension. ${ }^{18,19,20,21}$

\section{Method}

The design of this research used analytic observational research and this research was included in the cross-sectional study. The research was conducted in September-February 2020. The sample used in this study was 60 people with Primary Hypertension through appropriate purposive sampling method.

\section{Result}

The subjects of the researchwhere conducted were 60 people with a diagnosis from a primary hypertension doctor and the sampling was adjusted according to inclusion criteria.

\section{Regression Model I:}

Table 1 (Regression model I Variable X3, X1, and X2)

\begin{tabular}{|c|c|c|c|c|c|c|c|c|c|}
\hline Model & $\mathbf{R}$ & $\begin{array}{c}\text { R } \\
\text { Square }\end{array}$ & $\begin{array}{c}\text { AdjustedR } \\
\text { Square }\end{array}$ & $\begin{array}{c}\text { Std. Error of the } \\
\text { Estimate }\end{array}$ & $\begin{array}{c}\text { R Square } \\
\text { Change }\end{array}$ & F Change & df1 & df2 & Sig. F Change \\
\hline 1 &, $164^{\mathrm{a}}$ &, 027 &,- 024 & 20,452 &, 027 &, 527 & 3 & 57 &, 665 \\
\hline
\end{tabular}

1.Predictors: (Constant), Desire (X3), knowledge (X1), Relative (X2).

Table 2 (Contribution of Variable $X$ toward Variable $Z$ )

\begin{tabular}{|l|c|c|c|c|c|}
\hline Model & Sum of Squares & Df & Mean Square & F & Sig. \\
\hline Regression & 661,578 & 3 & 220,526 &, $665^{\text {b }}$ \\
\hline Residual & 23843,340 & 57 & 418,304 & & \\
\hline Total & 24504,918 & 60 & & \\
\hline Dependent Variable: TD_Hypertension (Z). & \\
\hline
\end{tabular}


Table 3 CoeffisienVariable X1, X2, and X3

\begin{tabular}{|c|c|c|c|c|c|}
\hline Model & UnstandardizedB & $\begin{array}{l}\text { Unstandardized } \\
\text { Std. Error }\end{array}$ & $\begin{array}{l}\text { Standardized } \\
\text { Coefficients Beta }\end{array}$ & $\mathrm{T}$ & Sig \\
\hline 1 (Constant) & 164,688 & 10,961 & & 15,026 &, 000 \\
\hline Knowledge(X1) &,- 183 & ,313 &,- 080 &,- 586 & ,560 \\
\hline Relatives(X2) &,- 249 & ,290 &,- 151 &,- 858 & ,394 \\
\hline Desire(X3) & 084 & ,275 &, 052 &, 305 & ,762 \\
\hline
\end{tabular}

a. Dependent Variable: TD_Hypertension (Z)

\section{RegressionModel II}

Table 4 (RegressionModel II Variable X3, X1, X2, and Z)

\begin{tabular}{|c|c|c|c|c|c|c|c|c|c|}
\hline Model & R & R Square & $\begin{array}{c}\text { Adjusted R } \\
\text { Square }\end{array}$ & $\begin{array}{c}\text { Std. Error of } \\
\text { the Estimate }\end{array}$ & $\begin{array}{c}\text { R Square } \\
\text { Change }\end{array}$ & F Change & df1 & df2 & Sig. F Change \\
\hline 1 &, $699^{\mathrm{a}}$ &, 489 &, 453 & 20,268 &, 489 & 13,401 & 4 & 56 &, 000 \\
\hline
\end{tabular}

a. Predictors: (Constant), TD_Hypertension (Z), desire (X3), knowledge (X1), Relatives (X2).

Table 5 Contributionof Variable Xand $Z$ toward $Y$

\begin{tabular}{|l|c|c|c|c|c|}
\hline Model & Sum of Squares & Df & Mean Square & F & Sig. \\
\hline 1 Regression & 22018,762 & 4 & 5504,691 & 13,401 &, $000^{\mathrm{b}}$ \\
\hline Residual & 23003,467 & 56 & 410,776 & & \\
\hline Total & $\mathbf{4 5 0 2 2 , 2 3 0}$ & $\mathbf{6 0}$ & & & \\
\hline
\end{tabular}

a. Dependent Variable: OHIS (Y).

b. Predictors: (Constant), TD_Hypertension (Z), Desire (X3), Knowledge (X1), relative (X2).

Table 6 Coeffisien ofVariable Xand $Z$ toward $Y$

\begin{tabular}{|l|c|c|c|c|c|}
\hline Model & Unstandardize B & $\begin{array}{c}\text { Coefficients Std. } \\
\text { Error }\end{array}$ & $\begin{array}{c}\text { Standardized } \\
\text { Coefficients Beta }\end{array}$ & T & $-1,499$ \\
\hline 1 (Constant) & $-36,252$ & 24,192 & &, 140 \\
\hline Knowledge (X1) &, 301 &, 311 &, 097 &, 338 \\
\hline Relative (X2) &, 606 &, 289 &, 272 & 2,098 &, 040 \\
\hline Desire (X3) &, 955 &, 273 &, 441 & 3,504 &, 001 \\
\hline TD_Hypertension (Z) &, 339 &, 131 &, 250 & 2,581 &, 012 \\
\hline
\end{tabular}

a. Dependent Variable: OHIS (Y)

\section{Discussion}

Tables 1, 2, and 3 explain the relationship of variable $\mathrm{X}$ against variable $\mathrm{Z}$ (Primary Hypertension). Based on the knowledge characteristics of respondents have a relationship at the level of education that affect respondents with Primary Hypertension. At a high level of education, it certainly will also influence in terms of knowledge that will support someone behaving that concerns the individual's needs. The knowledge of respondents with Primary Hypertension in this research influences the continuity of prevention or anticipates the disease does not get worse, affects the consumption of drugs that are only recommended not in long-term and the most priority thing in Primary Hypertension respondents in this research is able to restore lifestyle to be stable or improved. 
Extensive knowledge makes it easier to understand, digest, and comprehend the information that can be obtained either from social media or from information obtained from the family or relatives. Respondents with Primary Hypertension who are not handled properly by the doctor's advice will continue to become resistant hypertension or secondary hypertension, and new disease problems may arise, therefore, sufficient knowledge is very necessary to support the individual's understanding of the seriousness of diseases, especially primary hypertension.

That higher of the knowledge and understanding of health will also improve the way of viewing the concept of health and sickness into a stable which will ultimately affect the perspective, way of life and efforts to improve one's health status. ${ }^{22}$

Based on theresearch conducted the researcher wanted to see the relationship of respondent characteristics based on closest person to Primary Hypertension patients. Some people who visit the hospital and check themselves are encouragedby the family or relatives. ${ }^{23}$

Based on this researchwhere conducted the researcher wanted to see the relationship between the characteristics of respondents, namely the relationship of perception of desire towards patients with Primary Hypertension. Based on the understanding of researcher at the interview, the respondent who came himself to visit the hospital, take medication according to the doctor's recommendations, and follow the doctor's instructions is none other than the desire of the individual.

PameswariPuspa (2016) said that one's own desire plays an important role as astrong motivation from within, being a major factor in the high level of patient compliance in taking medication prescribed by the doctor and when it should be stopped. ${ }^{24}$

Tables 4, 5, and 6 explain the relation of the variable $\mathrm{X}$ is toward the variable $\mathrm{Y}$ (oral hygiene). Research conducted is relationship of the characteristics of respondents based on Knowledge. Knowledge and education are two things that cannot be separated because higher education will support higher insight and vice versa, but in this research these two things do not guarantee that respondents who have a higher education and extensive knowledge are able to maintain a clean and healthy oral or otherwise.
Respondents also suggested that knowledge of dental and oral health due to the lack of several health services was promoted through counseling, conducted either from the health center or health department students. Knowledge obtained by respondents is also still considered trivial for some respondents who tend not to apply in everyday life to maintain oral hygiene and can have an impact on dental and oral health problems, so the relationship of knowledge to oral hygiene does not have a very significant relationship.

Thisresearch also found the relationship between characteristics of respondents namely relativestoward Oral Hygiene. Some respondents who came alone did not guarantee that their family did not care about the respondent, but based on interviews conducted with respondents who came by themselves said that the family plays an important role in supporting the desire of patients to seek treatment.

Based on the research conducted at the perception of familyor relatives has a great influence for each individual to keep oral hygiene in maintaining oral health problems which can also have an impact on general body health. Thisresearch also consists of the relationship between the characteristics of respondents namely the desire toward oral hygiene where this condition is the reason for patients to check themselves because they have desire that is subjective, in this case the desire is something that cannot be measured or assessed.

People are really need treatment, but to get it, is strongly influenced by individual desires. This is known as the "need and demand of oral health". The need for care is not always followed by demand because it depends on the individual. It is Influenced by several things, namely quality of life and perception of needs (need), psychological factors, belief in health conditions (behavior, values, and habits), social structure (education and culture), demographics (age, gender, income, facilities, and distance). ${ }^{25}$

In the research conducted at wherevariable $\mathrm{Z}$ which is Primary Hypertension toward $\mathrm{Y}$ is (OHI-S) 0.012 $<0.05$, it can be concluded that there is a significant direct effect of the $\mathrm{Z}$ variable towardvariable $\mathrm{Y}$. However, in the research conducted, these respondents are not recommended to take long-term medication, it only lasts 3 days, after that it is stopped, because the respondent is given the drug only to lower blood pressure which suddenly rises. 
This is supported by theory that explains the proper use of anti-hypertensive drugs influenced by adherence (compliance or adherence) which is described the extent to which patients follow medical instructions or advice. Disobedience to treatment will result in high rates of treatment failure, so that in patients with primary hypertension the administration of the drug is only temporary to stabilize the increased blood pressure for patients. ${ }^{22,26,27,28}$

Research in cases of hypertension patients whom has been suffering for 2 years, so that the consumption of anti-hypertensive drugs must be continuous, the working process of the drug affects the salivary glands which can lead to xerostomia. Hypertension or famously known as the silent killer is a condition where the increase of blood pressure above normal. ${ }^{29,30}$

\section{Conclusion}

There is a relationship between perception of dental care toward oral health in patients with primary hypertension but it did not appear significantly.

Conflicts of Interest: The authors alone are responsible for the views expressed in this article and they do not necessarily represent the views, decisions, or policies of the institutions with which they are affiliated.

\section{Source of Funding: None.}

Ethical Clearance: Ethical Clearance was obtained from Universitas Muslim Indonesia; with number" 476/A/KEPK-UMI/IX/2019. Just before the interview, written consent was obtained from each participant in Universitas Muslim Indonesia guidelines.

\section{References}

1. Masriadi, FebriantoArif. Effectiveness of ergonomic gymnastics on decreasing blood pressure in patients with stage one hypertension, Indonesia. Indian Journal of Forensic Medicine \& Toxicology, 2018; 12[3]: 280-284

2. Masriadi. Epidemiology of non-communicable diseases. Jakarta: CV. Trans Info Media, 2016

3. Masriadi, RahmawatiAzis, ehaSumantri, Anwar Mallongi. Effectiveness of non pharmacologi therapy through surveillance approach to blood pressure degradation in primary hypertension patients, Indonesia. Indian Journal of Public Health Research \& Development, 2018; 9(2): 249-255
4. Masriadi, Muhammad Samsul Arifin, RahmawatiAzis. Effect of supervisory drink drugs (SDG) on decreasing blood pressure reduction in hypertension patients, Indonesia. Indian Journal of Forensic Medicine \& Toxicology, 2019; 13(3): 385-390

5. Masriadi, SumantriEha. Effectiveness of foot soak therapy with warm water on decreasing blood pressure in patients with stage one hypertension, Indonesia. Indian Journal of Forensic Medicine \& Toxicology, 2019; 13(3): 291-296.

6. Musfirah, Masriadi. Risk factor analysis with the incidence of hypertension in the working area of the Takalala Community Health Center in Marioriwawo Subdistrict, Soppeng District. Journal of Global Health, 2019; 2(2): 94-102.

7. Tambuwon, Prisalia. Description of complaints in the oral cavity in antihypertensive drug users in the Internal Medicine Polyclinic Robert Wolter Monginsidi Level III Hospital Manado. Medical Journal, 2015; 3(2): 241-245.

8. Ministry of Health of the Republic of Indonesia. INFODATIN Hypertension. 2018

9. Aulia, Rizki.Influence of knowledge on hypertension patient compliance in the Outpatient Hospital Dr. Moewardi Surakarta. Journal of Pharmacy, 2018; 2(3): 1-12.

10. Ministry of Health of the Republic of Indonesia. 2018. Basic health research. Jakarta: Balitbang

11. Zenurrohma, Destiara, Hesriantica. Relationship between knowledge and hypertension with the control of blood pressure in the elderly. Indonesian Public Health Journal, 2017; 5(2): 174-184.

12. Basuni, Cholil, Debykania, Tri Putri.An overview of the oral hygiene index based on the level of community education in Guntung Ujung Village, Banjar Regency. Journal of Dentistry. 2014; 2(1): 18-23.

13. Wati, Fauziah, Rachman. The effect of selfcare on the oral hygiene status of students with visual impairments. Journal of Dentistry, 2014; 3(4): 2333.

14. Wotulo, Febrina G, dkk. Differences in the flow rate of saliva in amlodipin and katopril antihypertensive drug users in Tumobui Urban Village, Kotamobagu City. Medical Journal. 2018; 6(1): 39-43.

15. Khoerunnisa, Novia. Relationship between the degree of Xerostomia with salivary $\mathrm{PH}$ after 
radiotherapy of Head and Neck Cancer. Medical Journal. 2017; 6(2): 983-992.

16. Hiremath,SS. Textbookof Preventiveand community dentistry.Newdelhi: Elsevier.2007

17. Verma, Dr. Mahesh. Textbook of preventifand community dentistry (Public Health Dentistry). Third edition. Indian: Josep John (CBS). 2017.

18. Tjokroprawiro, Askandar.Internal medicine textbook. Edisi 2. Surabaya: Airlangga University Press (AUP). 2015

19. Soenarta, Arieska Ann. Guidelines for the management of hypertension in cardiovascular disease. Edisi 1. 2015.

20. Adrianus, Kosasih. Consensus on Management of Hypertension. Jakarta, 2009.

21. America Heart Association (AHA). Highlights from the 2017 Guideline for The Prevention, Detection, Evaluation and Management of High Blood Pressure in Adults A Report of The American College of Cardiology/American Heart Association Task Force on Clinical Practice Guidelines. 2017.

22. Rahardjo, Setiyowati. Relationship between education and knowledge level with nutrition conscious family behavior in urban and rural communities in Banyumas Regency. Medical Journal, 2017; 4(2): 150-158.

23. Irnawati, Ni Made. The influence of family support for medication adherence in patients with hypertension at Motoboi Kecil Community Health
Center Mobagu City. Medical Journal, 2016; 4(1): 59-64.

24. Pameswari, Puspa, dkk. The level of compliance with drug use in hypertension patients at Mayjen H. A. Thalib Hospital in Kerinci Regency. Journal of Pharmacy, 2016; 2(2): 116-121.

25. Rahman, Fathul. Factors affecting the demand for dentures in the elderly (review of the costs of maintenance, anxiety, and facilities). Journal of Dentistry. 2016; 13(1): 5-11.

26. Tawas, Stevary. A.D, Elderly Xerostomia in Malalayang Satu Timur Village. Medical Journal, 2018; 6(1). 11-20.

27. Tyashapsari, MM Woro. The use of drugs in hypertensive patients at the Inpatient Inpatient Dr. Kariadi Semarang. Journal of Pharmacy. 2016; 8(2): 145-151.

28. Fitrianto, Heri. The use of antihypertensive drugs in patients with essential hypertension in the Hypertension Kidney Polyclinic RSUP DR. M. Djamil. Medical Journal. 2014; 3(1): 45-48.

29. Rawung, Feiby. Effects of alcoholic mouthwash on salivary flow rate and salivary PH. Medical Journal. 2017; 5(2): 125-129.

30. Masriadi, Eva AFZ, Ilmianti, at all. Relationship between Nutritional Status and Dietary Intake with Tooth Loss on Hypertension Patients at Padongko Health Center of Barru Regency. La Prensa Medica Argentina. 2020; 106(6): 1-5 